\title{
Identification Of Slip Surface In Mass Movement Zone In Kuantan Singingi Regency Province Of Riau Based On Geoelectricity Method And Cone Penetrating Test
}

\author{
Rizka Anggraini ${ }^{1}$, Rahmat Nawi Siregar ${ }^{2}$, Agus Hendratno $^{3}$, Sismanto $^{1}$ \\ ${ }^{1}$ Department of Physics, Gadjah Mada University, Sekip Utara BLS 21 Yogyakarta, Indonesia \\ ${ }^{2}$ Department of Physics, University of Bangka Belitung, Babel, Indonesia \\ ${ }^{3}$ Department of Geology Engineering, Gadjah Mada University, Yogyakarta, Indonesia
}

\begin{abstract}
Slip surface in mass movement zone in Kuantan Singingi Regency has been identified by using geolectricity with dipole - dipole configuration and Cone Penetrating Test measurement. The research has been applied in 8 geolectricity sites and 8 CPT sites in 3 different subdistricts. Slip surfaces have been identified in line 1 at $1.5 \mathrm{~m}$ depth, $3.2 \mathrm{~m}$ depth in line 2, $1.6 \mathrm{~m}$ depth in line 3, $3.6 \mathrm{~m}$ depth in line 4, $10.8 \mathrm{~m}$ depth in line 5, $5.2 \mathrm{~m}$ depth in line 6, $6.8 \mathrm{~m}$ depth in line 7 and $10.12 \mathrm{~m}$ depth in line 8. Every site have $>60^{\circ}$ slope which are classified into extreme slope. The most extreme slope and most dangerous site is line 7 in Jalan Raya Taluk Kuatan - Muara Lembu with $63^{\circ}$ slope and $10.2 \mathrm{~m}$ sediment thickness. The layer which is classified as slip surface is bedrock layer, where mass movement is translation type.
\end{abstract}

Keywords: Slip Surface, Geoelectricity, Cone Penetrating Test

\section{Introduction}

The mass movement pre-estimation map in Riau Province by Badan Meteorologi, Klimatologi dan Geofisika (BMKG) shows the low potential mas movement almost in all region. But, there are some medium potential mass movements in Southern Riau Province as shown in Figure 1.

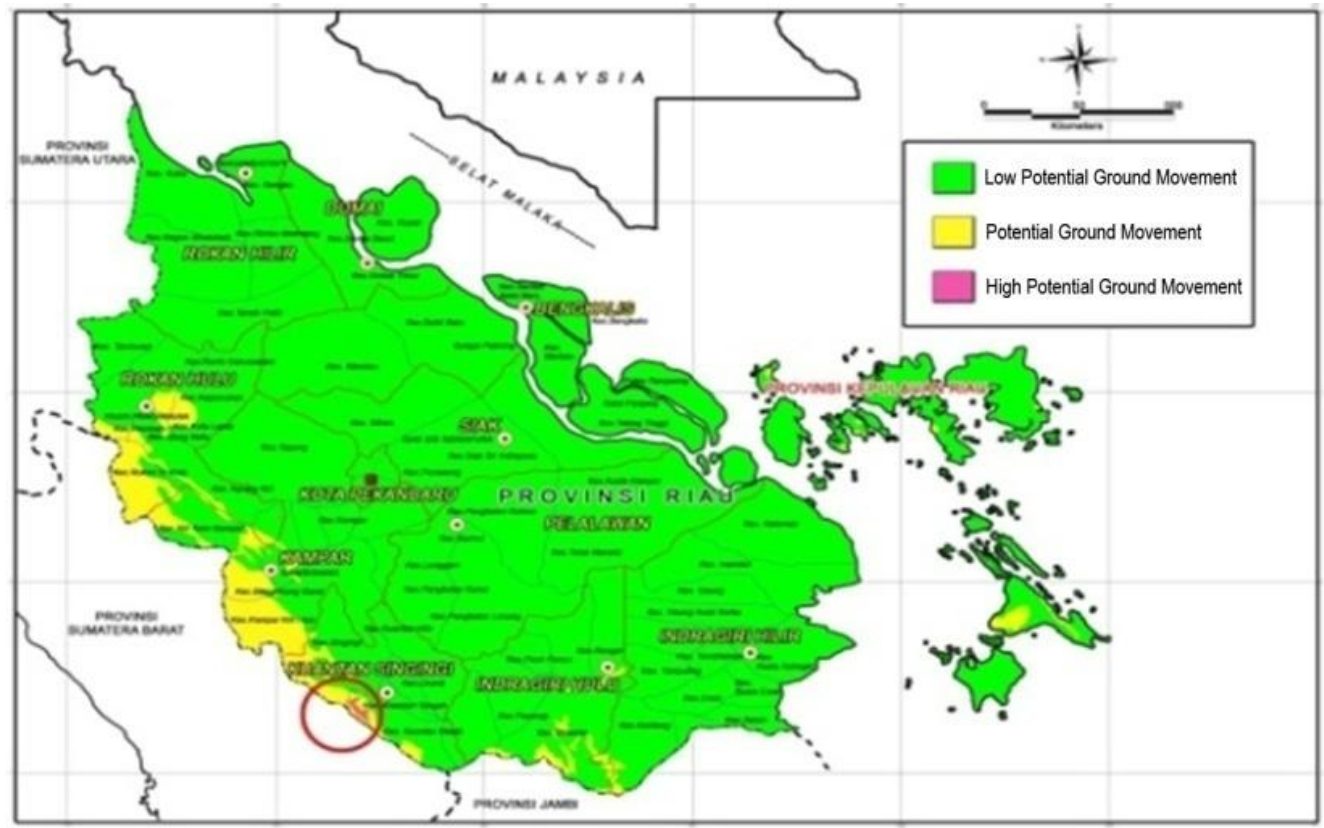

Figure 1. Pre-estimation map of mass movement in Riau [1]

The Mining and Energy Department of Riau Province publishes mass movement high potential in Kuantan Singingi Regency. It shows that western Kuantan Singingi is classifed into vulnerable to mass movement. The potential area are Singingi Hilir Subdistrict, Singingi Subdsitrict, Hulu Kuantan Subdistrict, Kuantan Mudik Subdistrict and Pucuk Rantau Subdistrict as shown in Figure 2. 


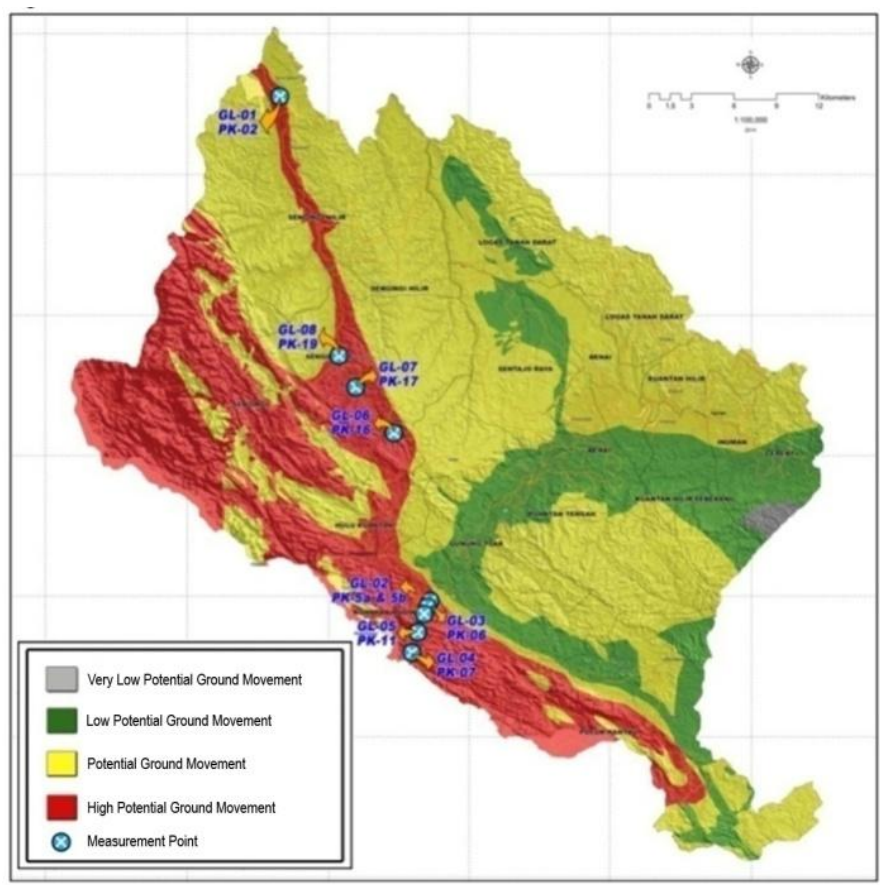

Figure 2. Vulnarability map of mass movement in Kuantan Singingi Regency and research area distribution [2]

Slip surface identification in vulnerable zones use geoelectricity method and cone penetrating test. These methods produce subsurface lithology in order to identify slip surface position and possible mass movement type. Kuantan Singingi Regency which is near by West Sumatra Province and Jambi Province hypothesize a possibility from earthquake trigger to mass movement in Kuansing Regency. Furthemore, the influence of earthquake to mass movement in Kuantan Singingi is desirable to identify.

Geological condition of Singingi Kuantan Regency consist of river aluvium, upper Palembang formation, middle Palembang formation, lower Palembang formation, lower Telisa formation, Tuhur formation, filit and shale of Kuantan formation, and lower Kuantan formation. Geoelectricity and CPT geological area are river alluvium, upper Palembang formation, filit and shale of Kuantan formation. Geological structures in this area which are fold (sinclyne and anticlyne) and faulting can be identified as vulnerable zone from some natural disaster such as landslide. Morphology of Kuantan Singingi regency are distributions of very rough, relatively rough, medium, and less rough relief mountain [4].

Mass movement is defined as land displacement from initial position. This movement is affected by distability of mass or rock as bedrock from the slope. The mass which move consist of soil, rock or fracture of soil mass and slope bedrock [5]. Mass movement is classified into 6 categories, translation, rotation, block movement, rockfall, rotation and soil creep. There are some factors contribute to mass movement such as rainfall and slope.

\section{Research Method}

Geoelectricity method use Resistivity Meter (G-Sound) GL-4100 type with dipole dipole configuration as far as $49 \mathrm{~m}$ for each line. Data from measurement are electricity current (I), potensial difference (V) and electrode space $(\mathrm{A}, \mathrm{B}, \mathrm{M}, \mathrm{N})$. Data processing was begun with input data from logsheet to microsoft office excel. From excel format, the data is converted to ext format in notepad, then processed by Res2dinv software to get resistivity profile. In order to observe good quality of lithology, data is processed by Progress software. Henceforth, resistivity profile is analyzed by concern to some parameters such as iteration number and convergence of Root Mean Square (RMS) error. The less RMS error, the better data are obtained because can be interpreted based on resistivity value and geological record of research area.

Cone Penetrating Test is applied in 8 different location which are near every geoelectirc lines. CPT method use 1 set of Bi-conus type Begemann with $250 \mathrm{~kg}$ capacity. Data from measurement are depth, conus resistance $\left(\mathrm{q}_{\mathrm{c}}\right)$, shear resistance $\left(\mathrm{f}_{\mathrm{s}}\right)$, ratio stress number $\left(\mathrm{R}_{\mathrm{f}}\right)$. Those data are changed to microsoft office excel to get CPT diagram. $\mathrm{q}_{\mathrm{c}}$ and $\mathrm{R}_{\mathrm{f}}$ data are processed by CpeT-It and converted to a graphic of Robertson soil Characteristic type. This graphic is used to explain soil characteristics in each depth based on $\mathrm{q}_{\mathrm{c}}$ and $\mathrm{R}_{\mathrm{f}}$. 
Identification Of Slip Surface In Mass Movement Zone In Kuantan Singingi Regency Province Of..

\subsection{Kuantan Mudik Subdistrict}

\section{Results And Interpretation}

Resistivty profile in line 1 (Figure 3) shows at $0-1.3 \mathrm{~m}$ depth, elevation $262.8-245 \mathrm{~m}$, resistivity range $26-120 \Omega \mathrm{m}$ which is interpreted as silt sand (thick blue). At $1.3-1.6 \mathrm{~m}$ depth and elevation $245-235 \mathrm{~m}$ are interpreted as sandy silt layer with resistivity range $180-250 \Omega \mathrm{m}$. At $1.6-11 \mathrm{~m}$ depth and elevation $235-$ $143.5 \mathrm{~m}$ are interpreted as limestone layer.

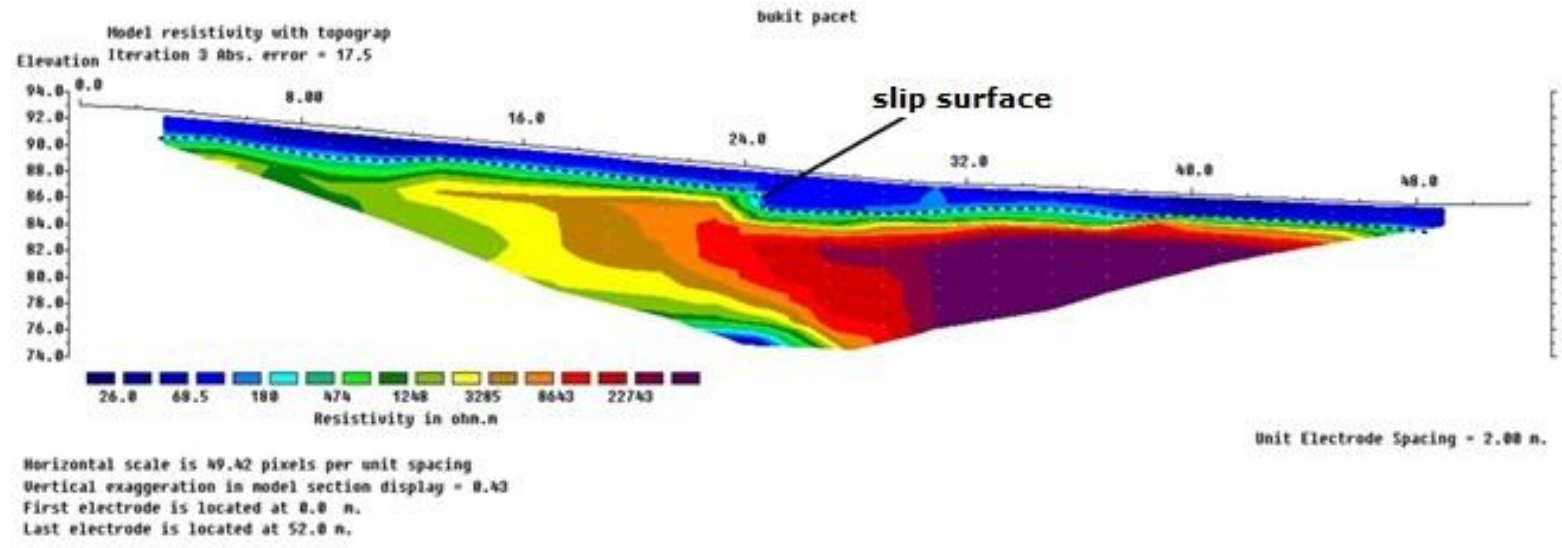

Figure.3. Resistivity profile in line 1

CPT graphic on Figure 3 shows that at $0-0.6$ meter depth, mean depth resistance is $53 \mathrm{~kg} / \mathrm{cm}^{2}$, shear ratio number is $1.08 \%$ and interpreted as soil layer with rigid consistency. $0.6-1.2 \mathrm{~m}$ Depth have conus resistancy at $106 \mathrm{~kg} / \mathrm{cm}^{2}$, shear ratio number is $1.2 \%$ and interpreted as soil layer with very rigid consistency. $1.2-1.6 \mathrm{~m}$ Depth have conus resistancy at $162 \mathrm{~kg} / \mathrm{cm}^{2}$, shear ratio number is $1.0 \%$ and interpreted as soil layer with rigid consistency. Maximum reach on PK 05 CPT is at $1.6 \mathrm{~m}$ depth with conus resistance $195 \mathrm{~kg} / \mathrm{cm}^{2}$, shear ratio number is $1.0 \%$ and interpreted as soil layer with rigid consistency.

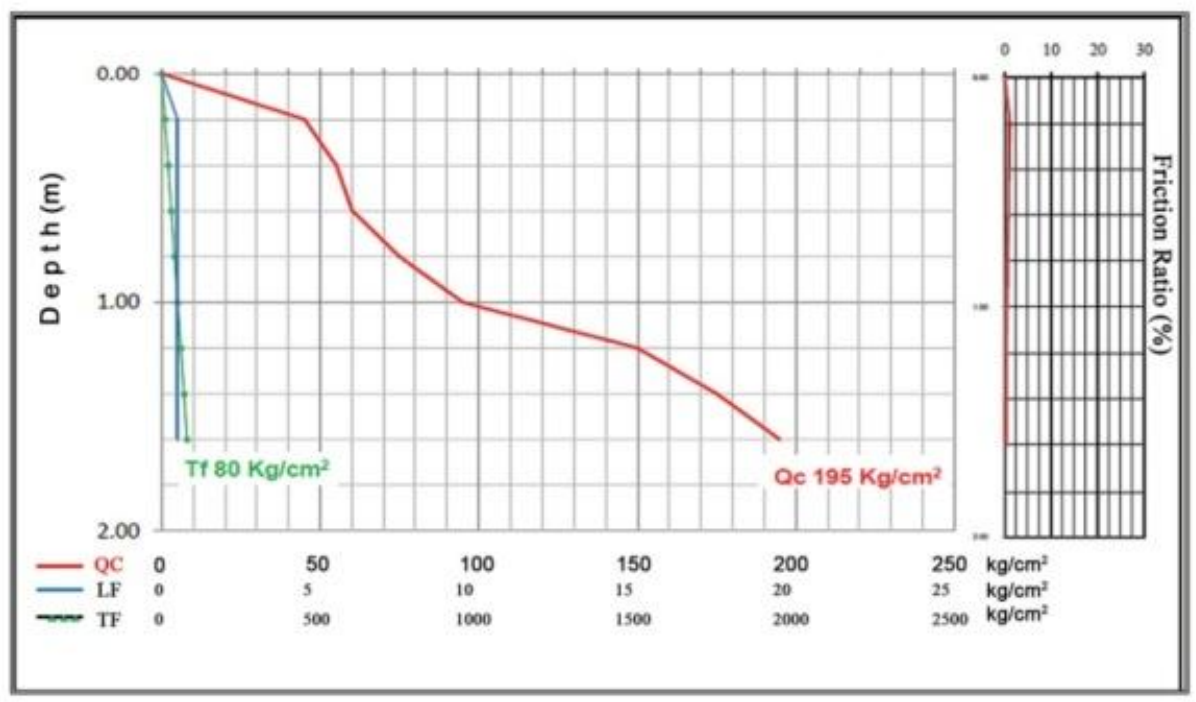

Figure 4. CPT graphic of PK 05

Characteristic soil diagram on PK 05 (Figure 4) shows that layer at $0.2-0.6 \mathrm{~m}$ depth is sand and sandy silt, $0.6-1.2 \mathrm{~m}$ depth is sand and the lower layer at $1.2-1.6 \mathrm{~m}$ is gravel sand layer and solidated sand. Geoelectricity and CPT data processing show soil characteristic at same depth $(1.6 \mathrm{~m})$ is bedrock which is estimated as slip surface with $62^{\circ}$ slope elevation. 


\section{Type of Soil Characteristics JPT (Robertson, 2010) \\ PK-5}

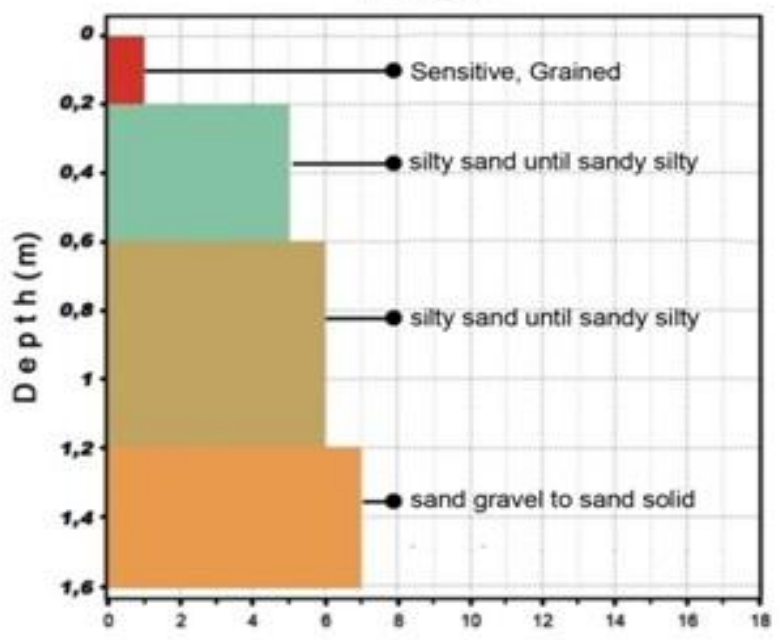

Figure 6. Lithology of PK 5 based on CPT

\subsection{Singingi Subdistrict}

Resistivty profile of line 1 (Figure 7) shows at $0-7.6 \mathrm{~m}$ depth, elevation $421-300 \mathrm{~m}$, resistivity range $100-461 \Omega \mathrm{m}$ which is interpreted as clay, sand and silty sand. At $5.5-10 \mathrm{~m}$ depth and resistivity $245-235 \Omega \mathrm{m}$ which are interpreted as sand layer. At $10.8 \mathrm{~m}$ depth and elevation $300-255 \mathrm{~m}$ are interpreted as igneous rock layer $(988-2110 \Omega \mathrm{m}$ ) and estimated as slip surface. Maximum reach on PK 16 CPT is at $10.7 \mathrm{~m}$ depth with conus resistance $195 \mathrm{Kg} / \mathrm{cm}^{2}$, shear ratio number is $1.6 \%$ and interpreted as soil layer with rigid consistency (Figure 7).

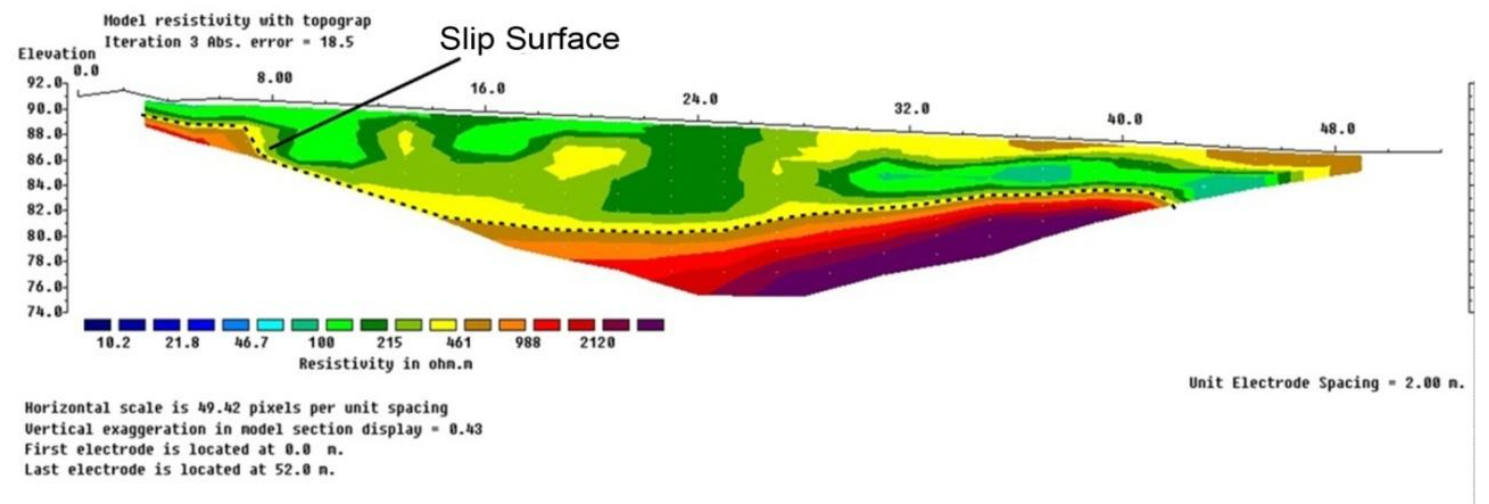

Figure. 7. Resistivity profile of line 7

CPT graphic on Figure 8 shows that at $0-6.3$ meter depth, mean depth resistance is $31 \mathrm{Kg} / \mathrm{cm}^{2}$, shear ratio number is $2.2 \%$ and interpreted as soil layer with tough consistency. $6.3-10 \mathrm{~m}$ Depth have conus resistancy at $83.4 \mathrm{~kg} / \mathrm{cm}^{2}$, shear ratio number is $1 \%$ and interpreted as soil layer with rigid consistency. $10-$ $10.6 \mathrm{~m}$ depth have conus resistancy at $172 \mathrm{~kg} / \mathrm{cm}^{2}$, shear ratio number is $1.6 \%$ and interpreted as soil layer with rigid consistency. 


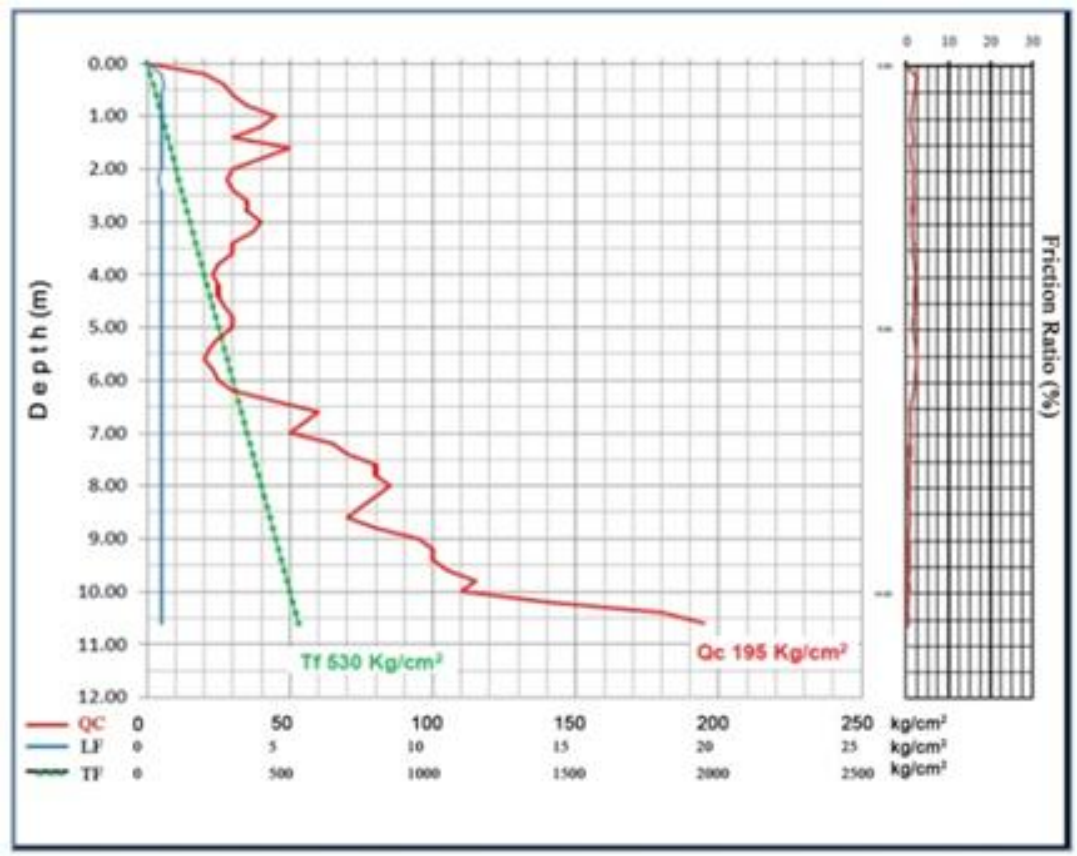

Figure 8. CPT result of PK 16

CPT graphic in figure 8 shows that at $0-6.3$ meter depth, mean depth resistance is $31 \mathrm{~kg} / \mathrm{cm}^{2}$, shear ratio number is $2.2 \%$ and interpreted as soil layer with tough consistency. The $6.3-10 \mathrm{~m}$ depth have conus resistancy at $83.4 \mathrm{Kg} / \mathrm{cm}^{2}$, shear ratio number is $1 \%$ and interpreted as soil layer with rigid consistency. $10-$ $10.6 \mathrm{~m}$ depth has conus resistancy at $172 \mathrm{Kg} / \mathrm{cm}^{2}$, shear ratio number is $1.6 \%$ and interpreted as soil layer with rigid consistency.

Characteristic soil diagram (Figure 9) shows that layer at $7.6 \mathrm{~m}$ depth is interlude between clay silt, sand - sandy silt, silt - sandy silt and sand - silty sand. Sand layer with $2.8 \mathrm{~m}$ thickness is found at $7.6 \mathrm{~m}$ depth. Soil layer below $10.4 \mathrm{~m}$ is interpreted as bedrock layer as slip surface. Subsurface interpretation of geoelectricity method is shown in figure 11 thatthe upper layer shows $5.5 \mathrm{~m}$ thickness of silt and the lower one claims sand layer existance from $5.5 \mathrm{~m}-10.6 \mathrm{~m}$ depth. $10.6 \mathrm{~m}$ depth is interpreted as bedrock layer and assumed as slip surface.

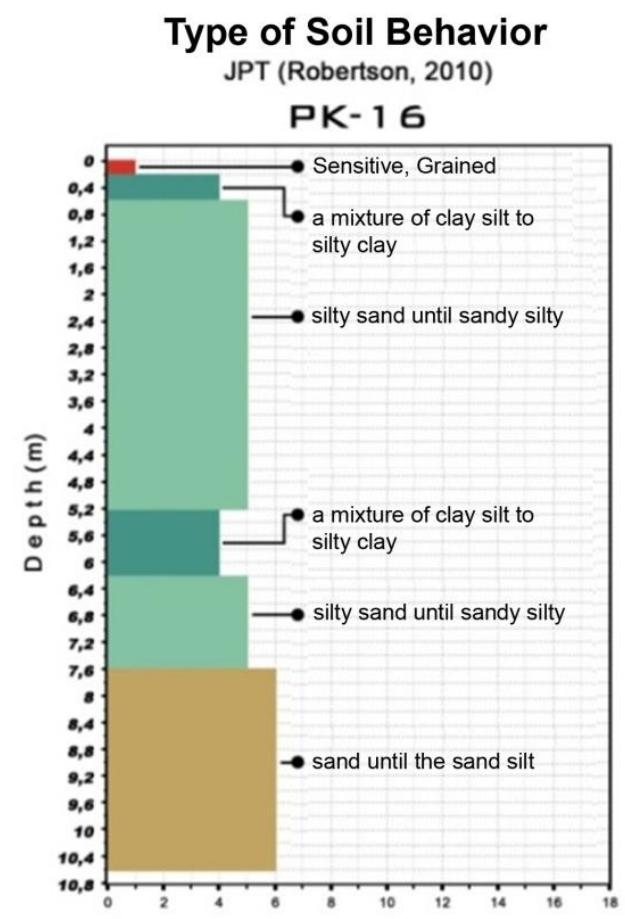

Figure 9. PK 16 soil Characteristic diagram 
Identification Of Slip Surface In Mass Movement Zone In Kuantan Singingi Regency Province Of..

\subsection{The effect of maximum Peak Ground Acceleration (PGA) to mass movement vulnerability in Kuantan Singingi Regency}

The PGA calculation is based on last 50 years earthquake history which show that PGA distribution does not affect landfall vulnerability zone at all. It is caused by bedrock PGA is very small, around $0.01-0.02$ g. PGA values from each area are shown in Table 1.

Table 1. Maximum PGA of Kuantan Singingi

\begin{tabular}{|c|l|l|c|c|}
\hline No & \multicolumn{1}{|c|}{ Lattitude } & \multicolumn{1}{|c|}{ Longitude } & PGA $\left(\mathrm{gal}=\mathrm{cm} / \mathrm{s}^{2}\right)$ & PGA $\left(\mathrm{g}=9.8 \mathrm{~m} / \mathrm{s}^{2}\right)$ \\
\hline $\mathbf{1}$ & $101^{\circ} 16^{\prime} 47,1^{\prime \prime}$ & $0^{\circ} 04^{\prime} 50,1^{\prime \prime}$ & 26.881 & 0.027429592 \\
\hline $\mathbf{2}$ & $101^{\circ} 27^{\prime} 15,6^{\prime \prime}$ & $0^{\circ} 40^{\prime} 44,6^{\prime}$ & 13.654 & 0.013932653 \\
\hline $\mathbf{3}$ & $101^{\circ} 27^{\prime} 10,0^{\prime \prime}$ & $0^{\circ} 40^{\prime} 47,9^{\prime \prime}$ & 13.663 & 0.013941837 \\
\hline $\mathbf{4}$ & $101^{\circ} 27^{\prime} 07,4^{\prime \prime}$ & $0^{\circ} 41^{\prime} 06,1^{\prime}$ & 13.689 & 0.013968367 \\
\hline $\mathbf{5}$ & $101^{\circ} 25^{\prime} 44,0^{\prime \prime}$ & $0^{\circ} 44^{\prime} 36,4^{\prime}$ & 14.756 & 0.015057143 \\
\hline $\mathbf{6}$ & $101^{\circ} 26^{\prime} 27,4^{\prime \prime}$ & $0^{\circ} 42^{\prime} 12,0^{\prime \prime}$ & 14.094 & 0.014381633 \\
\hline $\mathbf{7}$ & $101^{\circ} 24^{\prime} 32,3^{\prime \prime}$ & $0^{\circ} 28^{\prime} 24,7^{\prime}$ & 16.864 & 0.017208163 \\
\hline $\mathbf{8}$ & $101^{\circ} 21^{\prime} 50,3^{\prime \prime}$ & $0^{\circ} 24^{\prime} 43,3^{\prime \prime}$ & 18.542 & 0.018920408 \\
\hline $\mathbf{9}$ & $101^{\circ} 20^{\prime} 52,1^{\prime \prime}$ & $0^{\circ} 23^{\prime} 00,3^{\prime \prime}$ & 19.286 & 0.019679592 \\
\hline
\end{tabular}

\section{Conclusion}

The mean slope elevation of Kuantan Sengingi is around $62.7^{\circ}$. The highest landfall potential area is Jalan Raya Taluk - Kuantan - Muara Lembu with $63^{\circ}$ elevation and sediment thickness reaches $10.2 \mathrm{~m}$. The slip surface is bedrock layer and classified into translation type of landfall. PGA value in Kuantan Singingi Regency is relatively small. It is caused by a phenomenon where earthquake hypocenter was far away from the reasearh area, so earthquake can’t trigger soil on mass movement cases in Kuantan Singingi area.

\section{Acknowledgements}

This work was cooperation with mining and energy agency province of Riau. The author wish to thanks the directors of Publishing and Publication Department of Gadjah Mada University for permission to publish this article. Thankfully to mining and agency province of Riau for suppported geoelectrical equipment and permission cone penetrating test data and analysis. Thanks are due to all field team for their cooperation and support during field works.

\section{References}

[1]. A, P., Kusuma, Peta Kerentanan Gerakan Tanah Tahun Provinsi Riau, 2009, Pusat Lingkungan Geologi, Bandung.

[2]. Hendratno, Peta Kerentanan Gerakan Tanah Kabupaten Kuantan Singingi Provinsi Riau, 2014, Dinas Pertambangan dan Energi Provinsi Riau, Pekanbaru.

[3]. Anonim, 2008, Peta Geologi Kuantan Singingi, Dinas Pertambangan dan Energi Provinsi Riau, Pekanbaru.

[4]. Hendratno, Studi Kerentanan Gerakan Tanah Kabupaten Kuantan Singingi Provinsi Riau, 2014, Dinas Pertambangan dan Energi Provinsi Riau, Pekanbaru.

[5]. D., Karnawati, Mekanisme Gerakan Massa Batuan Akibat Gempa Bumi, Tinjauan dan Analisis Geologi Teknik. Dinamika Teknik Sipil, Vol. 7 No 2, Juli 2007: hal 179-190. Universitas Gadjah Mada, Yogyakarta.

[6]. Anonim, 1986, Pedoman Penyusunan Pola Rehabilitas Lahan dan Konservasi Tanah, Direktorat Reboisasi dan Rehabilitas Hutan, Jakarta.

[7]. Soedradjat, G, M., 2008, Bencana Gerakan Tanah di Indonesia, Pusat Vulkanologi dan Mitigasi Bencana Geologi, Bandung 